\title{
IDENTIFIKASI KONSEP SUKAR DAN KESALAHAN KONSEP REAKSI REDOKS
}

\section{IDENTIFICATION OF DIFFICULT CONCEPTS AND MISCONCEPTIONS OF REDOX REACTION}

\author{
Trining Puji Astutik ${ }^{1, *}$, Fariati $^{2}$, Herunata $^{3}$ \\ ${ }^{1}$ Program Studi Tadris Kimia, FTK, UIN Antasari Banjarmasin \\ Jl. A. Yani KM 4,5 Banjarmasin, 70235, Kalimantan Selatan \\ ${ }^{2}$ Prodi Kimia ${ }^{3}$ Prodi Pendidikan Kimia, Jurusan Kimia, FMIPA, Universitas Negeri Malang \\ Jl. Semarang No 5 Malang, 65145, Jawa Timur
}

Alamat Korespondensi: ningtut@gmail.com

\begin{abstract}
The goals learning chemistry is students understand chemistry concept. Redox reaction is one of the abstract concept and necessary in learning more complex concept. Difficulties of students in learning chemistry concept cause difficulties concept and misconception. This research has aims to identify difficulties concept's and misconception of students. The research is a descriptive study. The instrument used is a diagnostic test as many as 14 questions, in multiple choice tests with five answers, with the answer reason, and strengthened by interviews. Finally, difficulties concept's students are (a) oxidation reaction based on gain and loss of oxygen; (b) reduction reaction based on electron transfer; (c) oxidizing agent; (d) reducing agent; and (e) oxidation number, and misconception of students are (a) oxidizing agent increase in oxidation number; (b) reducing agent is a substances having the reduction reaction; (c) oxidation number of monatomic ion is not equal to the charge and the index number indicate oxidation number of element; and (d) redox reaction in case of change of charge of polyatomic ions into the compound.
\end{abstract}

Keywords: difficulties concept, misconceptions, redox reaction

\begin{abstract}
Abstrak
Tujuan pembelajaran kimia adalah siswa dapat memahami konsep kimia. Reaksi redoks merupakan salah satu konsep kimia bersifat abstrak dan berjenjang yang diperlukan dalam mempelajari konsep lebih kompleks. Kesukaran siswa dalam mempelajari konsep dapat menimbulkan konsep sukar dan kesalahan konsep. Penelitian yang dilakukan bertujuan untuk mengidentifikasi: konsep sukar dan kesalahan konsep yang dialami siswa. Penelitian yang dilakukan merupakan penelitian deskriptif. Instrumen yang digunakan adalah tes diagnostik sebanyak 14 butir soal tes pilihan ganda, 5 pilihan jawaban disertai alasan jawaban, dan diperkuat hasil wawancara. Hasil penelitian menunjukkan: (1) Konsep sukar adalah (a) reaksi oksidasi berdasarkan penggabungan dan pelepasan oksigen; (b) reaksi reduksi berdasarkan transfer elektron; (c) oksidator; (d) reduktor; dan (e) bilangan oksidasi, dan (2) Jenis kesalahan konsep yang dialami siswa adalah siswa menganggap: (a) oksidator mengalami peningkatan bilangan oksidasi; (b) reduktor adalah zat yang mengalami reaksi reduksi; (c) bilangan oksidasi ion monoatomik tidak sama dengan muatan ionnya dan angka indeks menunjukkan bilangan oksidasi; dan (d) reaksi redoks apabila terjadi perubahan muatan pada ion poliatomik menjadi senyawa.
\end{abstract}

Kata Kunci: konsep sukar, kesalahan konsep, reaksi redoks

\section{PENDAHULUAN}

Sastrawijaya (1988) mengungkapkan konsep kimia merupakan konsep berjenjang berkembang dari sederhana ke konsep lebih tinggi tingkatannya. Dengan demikian untuk memahami konsep lebih tinggi tingkatannya diperlukan pemahaman secara benar mengenai konsep dasar untuk membangun konsep tersebut. Menurut Wiseman (1981) bahwa hampir semua konsep ilmu kimia merupakan konsep abstrak, 
hanya dapat dipelajari dengan baik oleh siswa yang sudah mencapai tingkat berpikir formal ditinjau dari teori perkembangan intelektual Piaget. Kesukaran siswa mempelajari ilmu kimia diakibatkan kesukaran memahami konsep-konsep kimia dengan benar menyebabkan konsep tersebut merupakan konsep sukar bagi siswa. Konsep-konsep dalam kimia cenderung berkaitan satu dengan yang lain, kesalahan konsep dalam memahami suatu konsep cenderung menimbulkan kesalahan dalam memahami konsep lain yang berhubungan. Kesalahan konsep yang terjadi secara terus menerus serta menunjukkan kesalahan dengan sumber-sumber tertentu menunjukkan siswa mengalami kesalahan konsep (Berg dalam Pikoli, 2003). Salah satu konsep kimia abstrak dan berjenjang, misalnya konsep reaksi redoks berdasarkan transfer elektron, proses pelepasan dan penerimaan elektron tidak bisa dilihat dengan mata, tetapi hanya dibayangkan.

Konsep reaksi redoks merupakan salah satu materi berjenjang yang akan dipelajari secara mendalam dan kompleks pada materi elektrokimia. Konsep kimia yang dimiliki seorang siswa akan semakin berkembang seiring semakin tinggi jenjang pendidikan yang ditempuh karena konsep-konsep baru yang dipelajari semakin banyak, namun hal tersebut belum menjamin bahwa kesalahan konsep yang dimiliki siswa semakin kecil. Penelitian yang dilakukan bertujuan untuk mengidentifikasi konsep sukar dan kesalahan konsep yang dialami siswa.

\section{METODE}

Penelitian dilakukan pada siswa kelas $\mathrm{X}$ dan XI IPA SMA Laboratorium Universitas Negeri Malang di Jalan Bromo 16 Malang pada tahun ajaran 2009/2010. Sampel penelitian yaitu siswa kelas $\mathrm{X}_{1}$ sebanyak 33 siswa dan kelas XI $\mathrm{IPA}_{2}$ sebanyak 25 siswa. Instrumen berupa tes diagnostik sebanyak 14 butir soal tes obyektif yang diberikan alasan dan dilakukan tes wawancara.

\section{HASIL DAN PEMBAHASAN}

Konsep sukar pada siswa kelas $\mathrm{X}$ yaitu reaksi oksidasi, reaksi reduksi, oksidator, reduktor, dan bilangan oksidasi. Konsep sukar siswa kelas XI IPA yaitu reaksi reduksi, reduktor, dan bilangan oksidasi. Konsep paling sukar yang dialami kelas $\mathrm{X}$ adalah bilangan oksidasi pada soal nomor 6 dengan persen jawaban salah (PJS) sebesar 94\% dan yang dialami siswa kelas XI IPA adalah reaksi reduksi berdasarkan transfer elektron pada soal nomor 4 dan reduktor pada soal nomor 8 dengan PJS masing-masing sebesar $68 \%$. Dari 6 soal konsep sukar yang dialami siswa kelas X, terdapat 3 soal konsep sukar sama yang dialami dengan siswa kelas XI IPA.

Siswa kelas $\mathrm{X}$ mengemukakan bahwa reaksi oksidasi berdasarkan penggabungan dan pelepasan oksigen merupakan reaksi penggabungan senyawa atau unsur dengan oksigen tanpa mempengaruhi perubahan bilangan oksidasi. Pilihan jawaban A merupakan jawaban terbanyak hanya terjadi pada siswa kelas $\mathrm{X}$ yaitu sebesar 64\% sedangkan siswa kelas XI IPA hanya $16 \%$. Pada pilihan jawaban A, siswa mengemukakan bahwa reaksi oksidasi berdasarkan penggabungan dan pelepasan oksigen adalah reaksi penggabungan senyawa atau unsur dengan oksigen. Pada pilihan jawaban A, ada dua pilihan pada reaksi I merupakan reaksi oksidasi yang salah, sedangkan pada reaksi II merupakan reaksi oksidasi. Siswa sudah mengerti bahwa reaksi oksidasi adalah reaksi penggabungan antara senyawa atau unsur dengan oksigen, tetapi siswa belum mengerti bahwa dalam penggabungan dengan oksigen menyebabkan terjadi perubahan bilangan oksidasi.

Untuk pilihan jawaban E, hanya dipilih siswa kelas XI IPA sebesar 8\%, pemilihan jawaban $\mathrm{E}$ bukan disebut konsep sukar tetapi dikarenakan siswa tidak teliti dalam membaca soal.

Siswa kelas X dan XI IPA mengalami konsep sukar pada reaksi reduksi berdasarkan transfer elektron berturut-turut sebesar $82 \%$ dan $68 \%$. Konsep tersukar untuk siswa kelas XI IPA ada 2 konsep, salah satunya adalah konsep reaksi reduksi berdasarkan transfer elektron. Pada umumnya siswa kelas X menjawab soal nomor 4 pada pilihan jawaban $A$, menganggap terjadi reaksi reduksi karena terjadi perubahan bilangan oksidasi dari -6 menjadi -8 . Siswa sudah mengerti tetapi salah dalam menentukan zat yang terjadi reaksi reduksi. Pada soal nomor 4 menunjukkan bahwa persen pilihan jawaban (Px) terbanyak kelas $\mathrm{X}$ pada pilihan jawaban $\mathrm{A}$ sebesar $45 \%$.

Siswa sudah mengerti konsep reaksi reduksi, dalam penerapannya siswa belum bisa menentukan bilangan oksidasi masing-masing atom dalam ion poliatomik dan unsur yang mengalami reaksi reduksi. Pada pilihan jawaban $\mathrm{A}$ adalah $\mathrm{SO}_{3}{ }^{2-}$ menjadi $\mathrm{SO}_{4}{ }^{2}$. Bahwa jumlah bilangan oksidasi atom-atom dalam ion poliatomik sama dengan muatan ion tersebut. Bilangan oksidasi oksigen dalam senyawa adalah 
-2. Siswa pemilih pilihan jawaban A, tidak menganggap muatan pada ion poliatomik tersebut dan terjadinya reaksi reduksi karena perubahan bilangan oksidasi $\mathrm{O}$ adalah -6 (terdapat 3 atom $\mathrm{O}$ di ruas kiri, $3 \times-2$ ) menjadi -8 (4 atom $\mathrm{O}$ di ruas kanan, 4 x -2). Siswa mengemukakan bahwa $\mathrm{SO}_{3}{ }^{2-}$ merupakan reaktan yang mengalami reduksi. Siswa kelas XI IPA Px terbanyak pada jawaban B yaitu 28\%. Siswa mengemukakan bahwa $\mathrm{CO}_{3}{ }^{2-}$ merupakan reaktan yang mengalami reduksi. Pemilihan jawaban $\mathrm{B}$ menunjukkan siswa sudah mengerti tentang reaksi reduksi, tetapi siswa belum mengerti bahwa pelepasan oksigen terjadi pada senyawa bukan ion, dan pelepasan oksigen yang terjadi tidak menyebabkan perubahan bilangan oksidasi.

Pada konsep oksidator siswa kelas X dan XI IPA, Px terbanyak adalah pilihan jawaban E yaitu $64 \%$ untuk kelas X dan $24 \%$ untuk kelas XI IPA. Hampir semua siswa mengemukakan bahwa oksidator adalah zat yang mereduksi zat lain. Siswa juga menganggap bahwa oksidator adalah zat yang mengalami reaksi oksidasi sehingga terjadi kenaikan bilangan oksidasi dan bergabung dengan oksigen. Siswa masih belum mengerti konsep oksidator.

Konsep reduktor terdapat dalam 2 butir soal, yaitu soal nomor 8 dan 10. Pada soal nomor 8 merupakan soal hafalan tentang konsep reduktor. Pada soal nomor 10 adalah soal penerapan untuk menentukan reduktor dalam suatu reaksi redoks. Konsep sukar pada konsep reduktor hanya terjadi pada soal nomor 8 . Menurut siswa kelas X dan XI IPA reduktor adalah zat yang mengalami reaksi reduksi dan mengoksidasi zat lain. PJS konsep ini sebesar $64 \%$ untuk kelas X dan 68\% kelas XI IPA. Konsep ini tergolong sukar didasarkan pada alasan jawaban pada tes tertulis dan hasil wawancara, siswa masih belum memahami konsep reduktor.

Px terbanyak pada siswa kelas X dan XI IPA pada pilihan jawaban D yaitu sebesar $48 \%$ dan $32 \%$. Pilihan jawaban D merupakan pilihan yang terbanyak dipilih oleh siswa kelas X dan XI IPA berturut-turut 16 siswa dan 8 siswa. Pilihan jawaban D merupakan kesalahan yang dominan, menunjukkan siswa belum mengerti tentang reduktor. Siswa mengemukakan reduktor menyebabkan zat lain mengalami oksidasi. Siswa belum mengerti bahwa reduktor adalah zat yang mengalami reaksi oksidasi dan menyebabkan zat lain mengalami reduksi. Kesalahan ini juga dikarenakan siswa belum hafal Mg merupakan golongan 2 dalam Sistem Periodik Unsur, maka $\mathrm{Mg}$ memiliki bilangan oksidasi +2 , dan siswa masih belum bisa mengionkan. Pada $\mathrm{AgNO}_{3}$, siswa juga belum hafal bahwa ion nitrat $\left(\mathrm{NO}_{3}{ }^{-}\right)$ memiliki muatan -1 maka $\mathrm{AgNO}_{3}$ jika diionkan menghasilkan $\mathrm{Ag}^{+}$dan $\mathrm{NO}_{3}{ }^{-}$.

Soal nomor 6 dan 9 mengukur konsep bilangan oksidasi, merupakan konsep sukar untuk siswa kelas X dan XI IPA. Siswa kelas X mengalami konsep sukar pada soal nomor 6 dan 9, siswa kelas XI IPA mengalami konsep sukar hanya pada soal nomor 9. Soal nomor 6 merupakan konsep tersukar untuk siswa kelas X. Sebagian besar siswa kelas $\mathrm{X}$ menganggap suatu unsur bebas memiliki bilangan oksidasi sebesar angka indeksnya, seperti $\mathrm{P}_{4}$. Bilangan oksidasi $\mathrm{P}$ adalah +4 , begitu juga $S$ memiliki bilangan okidasi +8 pada $\mathrm{S}_{8}$. Berikut dijelaskan lebih lanjut tentang konsep bilangan oksidasi. PJS kelas X sebesar $94 \%$ untuk soal nomor 6, yang merupakan PJS terbesar dan $85 \%$ untuk soal 9.

Pilihan jawaban A banyak dipilih siswa kelas XI IPA. Pada pilihan jawaban A, siswa mengemukakan bahwa bilangan oksidasi $\mathrm{P}$ dan $\mathrm{S}$ berturut-turut +8 dan -2 . Siswa paham pada aturan bahwa jumlah bilangan oksidasi dalam senyawa adalah 0 , tetapi siswa tidak memperhatikan angka indeks yang menyebabkan kesalahan dalam menentukan bilangan oksidasi P. Pilihan jawaban $\mathrm{C}$ terbanyak dipilih siswa kelas X yaitu sebanyak 16 siswa dan tidak dipilih siswa kelas XI IPA. Siswa mengemukakan bilangan oksidasi molekul unsur sama dengan angka indeks, maka bilangan oksidasi $\mathrm{P}$ dan $\mathrm{S}$ berturut-turut +4 dan +8 . Siswa belum paham bahwa molekul unsur memiliki bilangan osksidasi 0.

Siswa kelas XI IPA yang memilih pilihan jawaban A yaitu 5 siswa, siswa mengemukakan bahwa bilangan oksidasi $\mathrm{N}$ dalam $\mathrm{Ba}\left(\mathrm{NO}_{3}\right)_{2}$ adalah +12 , bilangan oksidasi $\mathrm{H}$ pada $\mathrm{H}_{2} \mathrm{O}_{2}$ adalah +2 , dan $\mathrm{Cu}$ dalam $\mathrm{CuSO}_{4}$ adalah +1 . Siswa mengerti bahwa jumlah bilangan oksidasi dalam senyawa adalah 0 . Siswa belum bisa mengionkan dengan baik ditunjukkan kesalahannya pada $\mathrm{Ba}\left(\mathrm{NO}_{3}\right)_{2}$ dan $\mathrm{CuSO}_{4}$. Siswa tidak tahu bahwa ion nitrat memiliki rumus kimia $\mathrm{NO}_{3}{ }^{-}$dan ion sulfat $\left(\mathrm{SO}_{4}{ }^{2-}\right)$. Siswa hanya melihat jumlah atom dalam senyawa. Dalam hidrogen peroksida, siswa juga tidak hafal aturan bilangan oksidasi bahwa bilangan oksidasi $\mathrm{H}$ adalah +1 , kesalahan terjadi juga dikarenakan jumlah $\mathrm{H}$ ada 2. 
Tabel 1 Kesalahan Konsep Berdasarkan Pilihan Jawaban Siswa dengan Konsep yang Sama pada Soal yang Berbeda

\begin{tabular}{|c|c|c|c|}
\hline No & Konsep & No Soal & $\begin{array}{c}\text { Pilihan } \\
\text { Jawaban }\end{array}$ \\
\hline \multirow[t]{2}{*}{1.} & Siswa menganggap oksidator mengalami peningkatan bilangan oksidasi & 2 & $\mathrm{C}$ \\
\hline & & 13 & $\mathrm{~B}$ \\
\hline \multirow[t]{2}{*}{2.} & Siswa menganggap reduktor adalah zat yang mengalami reaksi reduksi & 8 & B \\
\hline & & 10 & $\mathrm{C}$ \\
\hline \multirow[t]{2}{*}{3.} & Siswa menganggap bilangan oksidasi ion monoatomik tidak sama dengan & 6 & $\mathrm{E}$ \\
\hline & muatan ionnya dan angka indeks menunjukkan bilangan oksidasi unsur & 9 & $\mathrm{E}$ \\
\hline \multirow[t]{3}{*}{4.} & Siswa menganggap reaksi redoks apabila terjadi perubahan muatan pada ion & 4 & $\mathrm{~B}$ \\
\hline & poliatomik menjadi senyawa & 5 & $\mathrm{~A} / \mathrm{C}$ \\
\hline & & 11 & A \\
\hline
\end{tabular}

Berdasarkan uraian konsep sukar reaksi redoks yang dialami siswa, untuk mengetahui kesukaran siswa yang meliputi sukar mendefinisikan konsep, sukar mengidentifikasi konsep, sukar membedakan konsep, dan sukar menghubungkan konsep yang satu dengan konsep yang lain.

Landasan penetapan siswa mengalami kesalahan konsep apabila secara konsisten menjawab pilihan jawaban kesalahan dengan konsep yang sama pada soal berbeda dan diperoleh 4 jenis kesalahan konsep dari 14 butir soal. Berikut ini akan dijabarkan masing-masing kesalahan konsep yang terjadi pada siswa kelas X dan XI IPA. Kesalahan konsep yang terjadi pada kelas $\mathrm{X}$ adalah konsep oksidator, bilangan oksidasi, dan reaksi redoks. Pada kelas XI IPA, salah konsep terjadi pada konsep reaksi oksidasi berdasarkan penggabungan dan pelepasan oksigen, oksidator, reduktor, bilangan oksidasi, dan reaksi redoks.

Berdasarkan data pada Tabel 1 diketahui bahwa salah konsep paling besar dialami siswa kelas $\mathrm{X}$ adalah konsep bilangan oksidasi yang ditunjukkan oleh jawaban siswa pada soal nomor 6 dan 9 dengan persentase kesalahan (PK) sebesar 33\%. Kesalahan konsep paling besar dari siswa kelas XI adalah konsep reaksi redoks pada soal nomor 4, 5, dan 11 dengan nilai PK sebesar $24 \%$.

Pada konsep oksidator dan bilangan oksidasi dialami siswa kelas X sebagai konsep sukar dan kesalahan konsep. Siswa kelas XI IPA mengalami konsep sukar dan kesalahan konsep pada konsep reduktor dan bilangan oksidasi. Jadi konsep bilangan oksidasi merupakan konsep sukar dan kesalahan konsep untuk kelas X dan XI IPA.

\section{a. Siswa Menganggap Oksidator Mengalami Peningkatan Bilangan Oksidasi \\ Kekonsistenan siswa memilih pilihan} jawaban $\mathrm{C}$ pada soal nomor 2 dan pilihan jawaban B soal nomor 13 menunjukkan kesalahan konsep karena oksidator merupakan zat yang mengalami reaksi oksidasi sehingga oksidator mengalami peningkatan bilangan oksidasi. Pilihan C pada nomor 2 dan B pada nomor 13 yaitu mengalami peningkatan bilangan oksidasi. Soal nomor 13 merupakan soal yang mengukur tentang pengertian oksidator, sedangkan soal nomor 2 untuk mengaplikasikan konsep oksidator. Kesalahan terjadi karena siswa belum mengerti bahwa sebenarnya oksidator adalah zat yang mengalami reduksi sehingga mengalami penurunan bilangan oksidasi dan mengoksidasi zat yang lain. Dalam penerapan konsep oksidator, siswa tidak bisa menentukan perubahan bilangan oksidasi $\mathrm{Cu}$. Kesalahan konsep ini dialami oleh siswa kelas X dan XI IPA sebanyak 3 siswa, 1 siswa kelas $X$ dan 2 siswa kelas XI IPA dengan PK berturut-turut sebesar $3 \%$ dan $8 \%$. Pernyataan diperkuat dengan hasil wawancara sebagai berikut.

P:"'Menurut Anda, apa yang disebut dengan oksidator?"

J:"Zat yang mengalami reaksi oksidasi."

P:"Jelaskan apa yang disebut reaksi oksidasi!"

$J$ :"Reaksi yang bergabung dengan oksigen, mengalami pelepasan elektron, dan peningkatan bilangan oksidasi.

P:"Apa kesimpulan mengenai oksidator?"

$J$ :"Zat yang mengalami reaksi oksidasi dan terjadi peningkatan bilangan oksidasi."

Berdasarkan hasil wawancara di atas bahwa oksidator adalah zat yang mengalami reaksi oksidasi dan terjadi peningkatan bilangan oksidasi. 


\section{b. Siswa Menganggap Reduktor adalah Zat yang Mengalami Reaksi Reduksi}

Konsep reduktor terletak pada soal nomor 8 dan 10. Berdasarkan kekonsistenan siswa menjawab pilihan jawaban B pada soal nomor 8 dan pilihan jawaban $\mathrm{C}$ pada soal nomor 10. Kesalahan konsep ini hanya terjadi pada 1 siswa kelas XI IPA, dengan PK sebesar 4\%. Pilihan jawaban B pada soal nomor 8 dan $\mathrm{C}$ pada soal nomor 10 adalah mengalami reduksi. Pada soal nomor 8 mengukur pengertian reduktor dan soal nomor 10 menentukan reduktor dari dua reaksi reaksi redoks. Konsep reduktor dibenak siswa merupakan zat yang mengalami reduksi maka dalam menjawab soal nomor 10 , siswa mencari ion dan senyawa yang mengalami reaksi reduksi atau mengalami penurunan bilangan oksidasi. Siswa menganggap bahwa reduktor adalah zat yang mengalami reaksi reduksi. Berikut salah konsep reduktor diperkuat hasil wawancara sebagai berikut.

P: "Reaksi redoks terdiri dari reaksi oksidasi dan reaksi reduksi dan zat yang mengalami reaksi tersebut oksidator dan reduktor. Apa yang disebut reduktor?"'

$J$ :"Reduktor adalah zat yang mengalami reaksi reduksi,

P:"Jelaskan tentang reaksireduksi?

J:" Reaksi reduksi adalah reaksi pelepasan oksigen, penerimaan elektron, dan reaksi yang terjadi penurunan bilangan oksidasi.

P:"Apa jawabanmu pada soal nomor 10 dan jelaskan!

J:"Saya memilih pilihan jawaban C yang merupakan reduktor yaitu $\mathrm{MnO}_{4}^{-}$dan $\mathrm{Ag}_{2} \mathrm{O}$. Pada reaksi I. $\mathrm{MnO}_{4}^{-}$menjadi $\mathrm{Mn}^{2+}$ terjadi reaksi reduksi karena terjadi penurunan bilangan oksidasi dari +7 menjadi +2. Reaksi II, $\mathrm{Ag}_{2} \mathrm{O}$ menjadi Ag terjadi penurunan bilangan oksidasi dari +2 menjadi 0 yang mengalami reaksi reduksi.

$P:$ :Apa kesimpulanmu tentang reduktor?"

$J$ :"Reduktor adalah reaksi yang mengalami reaksi reduksi.

Hasil wawancara menunjukkan kesalahan konsep siswa bahwa reduktor merupakan zat yang mengalami reaksi reduksi.

\section{c. Siswa Menganggap Bilangan Oksidasi Ion Monoatomik Tidak Sama Dengan Muatan Ionnya Dan Angka Indeks Menunjukkan Bilangan Oksidasi Unsur}

Siswa yang menjawab secara konsisten soal nomor 6 pilihan jawaban E, dan soal nomor
9 pilihan jawaban E. Kesalahan ini disebabkan siswa masih belum bisa mengionkan suatu senyawa. Siswa menganggap bilangan oksidasi ion monoatomik tidak sama dengan muatan ionnya dan angka indeks menunjukkan bilangan oksidasi unsur tersebut. Kesalahan konsep tersebut dialami siswa kelas $\mathrm{X}$ dan XI IPA. Kesalahan konsep terbanyak dialami oleh siswa kelas X yaitu sebesar 33\%, sedangkan kelas XI IPA sebesar $8 \%$. Soal nomor 6 merupakan soal yang menentukan bilangan oksidasi dan soal nomor 9 mengukur penentuan bilangan oksidasi yang benar. Pernyataan siswa mengenai kesalahan konsep bilangan oksidasi diperkuat dengan hasil wawancara sebagai berikut.

$P$ : "Coba tentukan bilangan oksidasi $\mathrm{C}, \mathrm{Cu}$, $\mathrm{P}$, dan $\mathrm{S}$ pada $\mathrm{CCl}_{4}, \mathrm{CuSO}_{4}, \mathrm{PI}_{3}$, dan $\mathrm{SCl}_{4}$ ?"

$J$ :"Masing-masing +1 karena jumlah $C$ ada 1, Cu ada 1, P ada 1, dan Sjuga ada 1."

Kesalahan konsep juga disebabkan siswa tidak bisa mengionkan, tidak tahu muatan suatu ion, dan penentuan golongan dalam sistem periodik unsur yang menyebabkan salah dalam menentukan bilangan oksidasi.

\section{d. Siswa Menganggap Reaksi Redoks apabila Terjadi Perubahan Muatan pada Ion Poliatomik menjadi Senyawa}

Kekonsistenan siswa memilih jawaban B pada soal nomor 4, jawaban A atau $\mathrm{C}$ soal nomor 5, dan jawaban B pada soal nomor 11 menunjukkan salah konsep reaksi redoks. Salah konsep terbanyak dialami oleh siswa kelas XI IPA yaitu sebesar 24\%, sedangkan kelas X sebesar 3\%. Salah konsep reaksi redoks merupakan kesalahan konsep tertinggi yang dialami siswa kelas XI IPA. Pada soal nomor 11 pilihan jawaban $\mathrm{B}$, siswa menganggap $\mathrm{CO}_{3}{ }^{2-}$ menjadi $\mathrm{CO}_{2}$ terjadi reaksi oksidasi karena terjadi perubahan bilangan oksidasi dari -2 menjadi 0 dan menganggap reaksi reduksi pada $\mathrm{H}^{+}$menjadi $\mathrm{H}_{2} \mathrm{O}$ yang mengalami perubahan bilangan oksidasi dari +1 menjadi 0 . Siswa menganggap reaksi redoks apabila terjadi perubahan muatan pada ion poliatomik menjadi senyawa. Salah konsep yang dialami siswa diperkuat hasil wawancara sebagai berikut.

$$
\begin{aligned}
& \text { J:"Ada yang mengalami reaksi oksidasi } \\
& \text { dan reduksi." } \\
& \text { P:"Coba jelaskan jawabanmu pada soal } \\
& \text { nomor 11!" } \\
& \text { J:"Pada pilihan jawaban B }
\end{aligned}
$$$$
\text { redoks?" }
$$$$
\text { P:"Bagaimana yang disebut reaksi }
$$ 


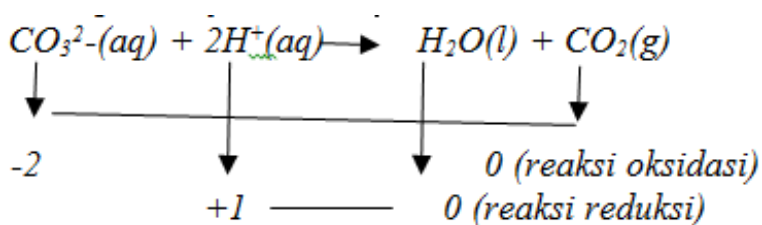

Berdasarkan hasil wawancara di atas menunjukkan bahwa reaksi oksidasi dan reduksi dilihat dari perubahan jumlah bilangan oksidasi suatu ion menjadi senyawa.

Berdasarkan analisis deskripsi konsep sukar dan kesalahan konsep yang dimiliki siswa kelas X dan XI IPA maka dapat disimpulkan kesukaran dan kesalahan konsep yang dimiliki siswa terjadi karena siswa hanya menghafal dan kurang memahami sehingga mudah lupa dan kesulitan mengerjakan soal.

Menurut Ansyari (2003) bahwa siswa SMU 3 Palu mengalami kesalahan memahami reaksi redoks antara lain: (1) reaksi redoks merupakan reaksi reduksi oksidasi yang terjadi secara terpisah dan tidak bersamaan, (2) reaksi reduksi adalah reaksi pelepasan elektron dan reaksi oksidasi adalah reaksi penerimaan elektron, (3) reaksi reduksi adalah reaksi yang mengalami peningkatan bilangan oksidasi dan reaksi oksidasi adalah reaksi yang mengalami penurunan bilangan oksidasi, (4) oksidator adalah zat yang mengalami reaksi oksidasi, sedangkan reduktor adalah zat yang mengalami reaksi reduksi, dan (5) reaksi autoredoks merupakan reaksi yang oksidator dan reduktornya adalah zat yang berbeda.

Handayani (2006) menemukan kesalahan konsep yang dialami siswa meliputi, (1) bilangan oksidasi unsur bebas tidak nol, (2) larutan nonelektrolit dapat dielektrolisis, dan (3) jembatan garam ikut dalam reaksi sel. Menurut Garnett dan Treagust (1992) konsep sukar yang dialami siswa antara lain, (1) bilangan oksidasi unsur sama dengan muatan ion monoatomik unsur tersebut, (2) perubahan muatan ion poliatomik dapat digunakan untuk mengidentifikasi reaksi redoks, dan (3) muatan ion poliatomik digunakan untuk menentukan elektron yang dilepaskan dan diterima.

Menurut Jong dkk (1995) topik reaksi redoks tidak hanya sulit dipelajari tetapi juga untuk diajarkan, reaksi redoks seharusnya lebih mudah dijelaskan dengan praktikum atau dihubungkan dengan kehidupan sehari-hari. Hal ini ditunjukkan hasil tes materi reaksi redoks siswa kelas $\mathrm{X}_{3}$ di SMA Laboratorium Universitas Negeri Malang tahun ajaran 2008/2009 dari 45 siswa, $73 \%$ memiliki nilai di bawah 75 . Menurut BSNP (2006:12) kriteria ideal untuk mencapai ketuntasan adalah dengan kriteria 75\%. Hal ini menunjukkan bahwa konsep reaksi redoks termasuk dianggap siswa sebagai materi yang sulit.

\section{KESIMPULAN}

Pada penelitian yang telah dilakukan menunjukkan bahwa siswa kelas X dan XI IPA mengalami konsep sukar dan kesalahan konsep reaksi redoks dikarenakan materi ini bersifat abstrak dan siswa belum memahami konsep secara utuh.

\section{SARAN}

Dalam penyampaian materi reaksi redoks guru diharapkan mengajarkan materi dengan menghubungkan konsep dengan kehidupan sehari-hari dan dilakukan praktikum. Dalam menyampaikan dan menjelaskan materi konsep redoks, hendaknya guru membantu siswa untuk membedakan unsur, ion, dan senyawa untuk menentukan bilangan oksidasi, ciri-ciri terjadinya reaksi redoks agar memperoleh pemahaman yang lebih mendalam. Tes diagnostik dapat digunakan dalam pembelajaran untuk mengetahui kesalahn konsep yang terjadi pada siswa.

\section{DAFTAR RUJUKAN}

Ansyari, R. (2003). Identifikasi KesalahanKesalahan dalam Memahami Materi Reaksi Redoks pada Siswa Kelas I SMU Negeri 3 Palu dan Upaya Perbaikannya dengan Menggunakan Metode Diskusi Kelompok. Tesis tidak diterbitkan. Malang: Program Pasca Sarjana Universitas Negeri Malang.

Garnett, P. J. \& Treagust, D. F. (1992). Conceptual Difficulties Experienced by Senior High Scool Students of Electrochemistry: Electric Circuit and Oxidation-Reduction Equations. Journal of Research In Science Teaching, 29(2), 121-142.

Handayani \& Tri P. (2006). Ident ifikasi Salah Konsep Reaksi Redoks dan Elektrokimia Siswa Kelas III SMAN 1 Trenggalek. Skripsi tidak diterbitkan. Malang: jurusan Kimia FMIPA Universitas Negeri Malang.

Jong, O. D., Acampo, J., \& Verdonk, A. (1995). Problem in Teaching the 
Topic of Redox Reactions: Actions and Conceptions of Chemistry Teachers. Journal of Research in Science Teaching, 32(10), 10971110.

Pikoli, M. (2003). Identifikasi Kesalahan Konsep dalam Ikatan Kimia pada mahasiswa Jurusan Pendidikan Kimia IKIP Negeri Gorontalo dan Upaya Memperbaikinya dengan Strategi Konflik Kognitif. Tesis tidak diterbitkan. Malang: program Pasca Sarjana Universitas Negeri Malang.

Sastrawijaya, T. (1988). Proses Belajar Mengajar Kimia. Jakarta: Depdikbud Dirjen Dikti PPLPTK.

Wiseman, F. L. (1981). The Teaching of College Chemistry Role of Student Development Level. Journal of Chemical Education, 58(6), 484-485. 